\title{
Penelitian Tentang Kesediaan Konsumen Untuk Membayar Produk Partisi Modular Ramah Lingkungan
}

\author{
Adryan A., Dimastyo L., Ferly S., Valentina A.G., dan Vania T.B. \\ School of Business and Economics Universitas Prasetiya Mulya \\ JL. RA. Kartini (TB Simatupang), Cilandak Barat Jakarta Selatan, Jakarta 12430 Indonesia.
}

*. Corresponding Author: adryan.adiwijaya@student.pmbs.ac.id

\begin{abstract}
Indonesia is a developing country where growth in various sectors is being intensively conducted, one of which is the construction sector. Sustainable development is then become a major concern of research where one of the factors contributing to sustainable development is building materials. The purpose of this study is to group and test the indicators in correspond to latent variable that is related to Mycotech's Floor Mounted Modular Wall System product purchase as an eco-friendly modular partition. Questionnaires are used for data collection with purposive sampling technique to 100 respondent. Collected data are then analyzed with exploratory factor analysis and linear regression. Study shows that contextual and perceptual factor such as individual perception, trust, behavioral commitment, standard quality, economic value, and product characteristic affect respondent willingness to pay eco-friendly product.
\end{abstract}

\footnotetext{
ABSTRAK

Indonesia merupakan negara berkembang dimana pertumbuhan di berbagai sektor sedang gencar dilakukan, salah satunya adalah sektor konstruksi. Pembangunan berkelanjutan kemudian menjadi perhatian utama penelitian dimana salah satu faktor yang berkontribusi pada pembangunan berkelanjutan adalah material bangunan. Tujuan dari penelitian ini adalah untuk mengelompokkan dan menguji indikatorindikator sesuai dengan variabel yang berhubungan dengan pembelian produk Floor Mounted Modular Wall System Mycotech sebagai partisi modular ramah lingkungan oleh konsumen. Penyebaran kuesioner digunakan untuk pengambilan data dengan teknik purposive sampling terhadap 100 responden. Data yang terkumpul kemudian dianalisis dengan exploratory factor analysis dan linear regression. Hasil dari penelitian ini menunjukkan bahwa faktor kontekstual dan faktor perseptual seperti persepsi individu, kepercayaan, komitmen perilaku, kualitas standar, nilai ekonomis, dan karakteristik produk mempengaruhi kesediaan responden untuk membayar produk ramah lingkungan.
}

\section{ARTICLE INFO}

Keyword : Perceptual factor, contextual factor, corporate environmental performance, willingness to pay

Kata Kunci : Perceptual factor, contextual factor, corporate environmental performance, willingness to pay 


\section{PENDAHULUAN}

Indonesia merupakan negara berkembang dimana gencar dilakukan pertumbuhan di berbagai sektor. Salah satu sektor yang sedang bertumbuh dengan pesat adalah sektor konstruksi. Menurut data Badan Pusat Statistik, kontribusi sektor konstruksi terhadap Produk Domestik Bruto (PDB) Indonesia pada tahun 2017 cukup besar, yaitu sebesar $10,26 \%$ atau peringkat keempat setelah sektor industri pengolahan, pertanian dan perdagangan. Sementara untuk tingkat internasional, data Global Competitiveness Index 2017 memperlihatkan bahwa indeks daya saing infrastruktur Indonesia pada tahun 2017-2018 berada di peringkat 52, naik 10 peringkat dari dua tahun sebelumnya atau berada di urutan keempat se-Asia Tenggara setelah Singapura, Malaysia dan Thailand. Pertumbuhan di sektor konstruksi ini juga berefek pada pertumbuhan ekonomi Indonesia. Pertumbuhan ekonomi di era global menciptakan suatu budaya konsumtif. Perubahan pola konsumsi mengarah pada perilaku konsumsi yang berlebihan dan mengakibatkan eksploitasi sumber daya secara berlebihan. Faktor keinginan manusia menjadi prioritas yang lebih tinggi dibandingkan nilai fungsi dari suatu produk.

Seiring dengan bertumbuhnya sektor konstruksi di Indonesia, di sisi lain kepedulian terhadap lingkungan juga menurun. Banyak kegiatan-kegiatan konstruksi yang justru merusak lingkungan. Pembangunan berkelanjutan kemudian menjadi perhatian utama penelitian di kalangan akademisi, praktisi, dan entitas industri. Penelitian sebelumnya membuktikan persepsi, sikap, pengetahuan tentang produk dan produsen, dan berbagai faktor kontekstual mempunyai peran dominan dalam proses pengambilan keputusan (Biswas \& Roy 2015). Kesediaan untuk membayar (willingness to pay) menunjukkan harga maksimum yang mau dibayarkan oleh individu untuk mendapatkan produk serta memiliki peran terhadap pengambilan keputusan.

PT Miko Bahtera Nusantara dengan nama merk Mycotech berdiri pada tahun 2013 dengan fokus untuk mengembangkan material bangunan baru dengan campuran limbah pertanian tanaman berserat dengan bibit miselium jamur. Mycotech memiliki tujuan untuk menghasilkan material ramah lingkungan yang dapat diproduksi secara masal. Dalam perkembangannya, Mycotech telah menciptakan produk partisi dinding modular yang diberi nama Floor Mounted Modular Wall System berukuran 2,4 x 0,9 meter dengan frame aluminium yang dijual pada harga Rp 3,1 - 3,6 juta per set. 
Penelitian ini dibuat dengan tujuan untuk mengelompokkan dan menguji indikatorindikator sesuai dengan variabel yang berhubungan dengan pembelian produk Floor Mounted Modular Wall System Mycotech sebagai partisi modular ramah lingkungan oleh konsumen. Indikator-indikator yang diteliti dalam penelitian ini seperti spesifikasi produk, harga yang ditawarkan, jaringan distribusi, persepsi individu dalam pemilihan produk yang ramah lingkungan, keputusan konsumen dalam pembelian produk yang ramah lingkungan, dan pemilihan produk ramah lingkungan sesuai dengan perusahaan yang memperhatikan lingkungan sekitar, dan kesediaan konsumen untuk membayar produk partisi modular ramah lingkungan.

Pada bagian II dijelaskan tentang variabel yang digunakan dan pada bagian III dijelaskan tentang metodologi penelitian. Hasil dari kuesioner berupa data kuantitatif akan diolah menggunakan software SPSS untuk meregresikan variabel-variabel penelitian yang telah dirumuskan. Analisis dan kesimpulan dari penelitian dibahas pada bagian IV dan V.

\section{TINJAUAN PUSTAKA}

Berdasarkan Journal of Advanced Management Science Vol. 4 tahun 2016 yang menggunakan penelitian exploratory factor analysis, terdapat studi tentang kesediaan membayar untuk produk ramah lingkungan. Dalam penelitian tersebut menyebutkan 11 indikator yang diteliti (Biswas 2016). Berikut adalah penjelasan tentang keempat faktor:

\section{a. Perceptual Factor}

Peningkatan tanggung jawab individu terhadap lingkungan akan memicu keputusan pembelian green product. Perceptual factor merupakan representasi rasa tanggung jawab terhadap lingkungan berdasarkan kemungkinan terjadinya kerusakan lingkungan yang diukur melalui persepsi individu, kepercayaan, dan komitmen perilaku (Biswas 2016). Persepsi akan dampak kesehatan lingkungan mempengaruhi individu dalam pemilihan dan pembelian suatu produk (Seguin 1998) juga terhadap niat melakukan green purchasing (Liu 2010). Perceptual dan contextual factor menjelaskan tentang motivasi perilaku manusia terhadap lingkungan.

\section{b. Contextual Factor}

Contextual factor adalah suatu faktor yang merefleksikan suatu konteks secara khusus, karakteristik unik terhadap kelompok tertentu, komunitas, sosial bahkan individu (Ferro et al. 2009). Contextual factor bisa memotivasi atau menjadi hambatan untuk perilaku terhadap lingkungan. Contextual Factor dicerminkan seperti karakteristik produk, standar 
kualitas, ketersediaan fasilitas daur ulang, market supply of goods, infrastruktur fisik, insentif kebijakan yang bisa mempengaruhi perilaku terhadap lingkungan dan niat konsekuen untuk membayar harga premium (Biswas 2016). Beberapa penelitian sebelumnya memiliki fokus dalam contextual factor yang mempengaruhi keputusan pembelian green product (Biswas 2016).

\section{c. Corporate Environmental Performance (CEP)}

Corporate Environmental Performance adalah hasil dari manajemen organisasi terhadap aspek lingkungan mereka (ISO 14031 2013). CEP membuat sebuah perusahaan ingin memiliki performa yang lebih baik melalui pengurangan dampak terhadap lingkungan dan perubahan yang dilakukan berdasarkan evaluasi konsumen (Biswas 2016). Praktik tanggung jawab sosial mencerminkan informasi kepada stakeholder tentang nilai organisasi dan berguna untuk meningkatkan kepercayaan pelanggan terhadap perusahaan. Dari penelitian sebelumnya didapatkan data yang menyarankan bahwa pembelian dipengaruhi oleh pengetahuan pelanggan yang spesifik seperti praktik dari CEP (Rodrigues \& Borges 2015). Ketika konsumen menerima informasi tentang kegiatan tanggung jawab sosial dari perusahaan yang dia percayai, informasi ini mempengaruhi cara mereka mengevaluasi perusahaan dan juga niat pembelian mereka (Mohr \& Webb 2015). Oleh karena itu, penelitian ini mempertimbangkan dimensi lingkungan CEP sebagai pendekatan terhadap kesediaan membayar konsumen.

\section{d. Willingness To Pay (WTP)}

Variabel ini mencerminkan kemauan maksimal individu untuk membayar produk atau jasa tertentu untuk dikonsumsi (Li \& Meshkova 2013). Willingness to pay dinilai sebagai pengukuran niat membeli yang dapat dianggap sebagai representasi yang realistis untuk perilaku yang sebenarnya (Pelsmacker et al. 2005). Tujuan untuk mengukur WTP dalam penelitian ini adalah menentukan karakteristik komprehensif yang tepat dari keputusan pembelian green product oleh konsumen.

Beberapa hipotesis digunakan untuk mendukung penelitian adalah sebagai berikut:

- H0: Faktor perseptual tidak mempengaruhi kesediaan untuk membayar produk partisi modular.

H1: Faktor perseptual mempengaruhi kesediaan untuk membayar produk partisi modular.

- H0: Faktor kontekstual tidak mempengaruhi kesediaan untuk membayar produk partisi modular. 
H1: Faktor kontekstual mempengaruhi kesediaan untuk membayar produk partisi modular.

- H0: Corporate environmental performance (CEP) tidak mempengaruhi kesediaan untuk membayar produk partisi modular.

H1: Corporate environmental performance (CEP) mempengaruhi kesediaan untuk membayar produk partisi modular.

\section{METODOLOGI PENELITIAN}

Jenis penelitian yang dilakukan adalah kuantitatif asosiatif, yaitu penelitian yang bersifat menanyakan hubungan antara dua variabel atau lebih (Sugiyono 2017). Penelitian ini dilaksanakan untuk mengetahui pengaruh dan hubungan dari faktor-faktor yang mempengaruhi kesediaan konsumen untuk membayar produk partisi modular dengan pengumpulan data secara kuantitatif melalui kuesioner ke responden.

A. Pengumpulan Data

Sumber data yang digunakan dalam penelitian ini dikumpulkan melalui survei kuesioner kepada 100 responden, informasi yang diperoleh secara langsung dari PT Miko Bahtera Nusantara serta informasi secara tidak langsung dari objek penelitian yang bersifat publik seperti informasi dari internet dan hasil publikasi.

B. Pengumpulan Data

Teknik penentuan sampel yang digunakan adalah purposive sampling untuk data kuesioner. Menurut Sugiyono (2017), purposive sampling adalah teknik penentuan sampel dengan pertimbangan tertentu. Alasan pemilihan sampel dengan menggunakan purposive sampling adalah karena tidak semua sampel memiliki kriteria sesuai dengan yang telah penulis tentukan. Oleh karena itu, sampel yang dipilih sengaja ditentukan berdasarkan kriteria tertentu yang telah ditentukan oleh penulis untuk mendapatkan sampel yang representatif. Populasi yang digunakan memiliki latar belakang di dalam bidang konstruksi dan pembangunan seperti konsultan arsitektur dan teknik sipil, developer, desainer interior dan kontraktor.

Jumlah sampel untuk penelitian ini menggunakan rumus dari Green (1991) yaitu $50+8 \mathrm{n}$, di mana $\mathrm{n}$ adalah jumlah variabel. Dalam penelitian ini terdapat empat variabel, maka dari itu dapat diperoleh perhitungan dengan menggunakan rumus 50+8n dan didapatkan jumlah sampel sebanyak 82 responden yang kemudian dibulatkan menjadi 100 responden. Sampel yang diambil oleh peneliti berdasarkan hasil perhitungan kurang 100 responden, sedangkan menurut Hair (2010) menyarankan bahwa untuk penelitian yang akan diolah 
dengan menggunakan multiple regression jumlah sampel minimum 50 responden dan lebih disarankan 100 responden.

Kriteria sampel yang dipilih adalah sebagai berikut:

1. Usia antara 21-55 tahun

2. Memiliki pengalaman bekerja minimal 1 tahun dalam bidang konstruksi dan pembangunan seperti konsultan arsitektur dan teknik sipil, developer, desainer interior dan kontraktor.

3. Pernah membeli green material atau terlibat dalam proyek green building

Metode pengumpulan data dilakukan melalui penyebaran kuesioner kepada sampel yang sudah ditentukan. Kuesioner dibagi menjadi tiga bagian dengan jawaban menggunakan skala likert untuk nilai 1 sebagai Sangat Tidak Setuju dan nilai 5 sebagai Sangat Setuju untuk mengetahui faktor-faktor yang mempengaruhi kesediaan konsumen dalam membayar produk partisi modular dan satu bagian memilih jawaban yang paling sesuai untuk demografi responden. Pertanyaan yang diajukan kepada responden terdiri dari 2 bagian tentang indikator-indikator dan demografi responden.

C. Pengolahan Data

Pengolahan data yang dilakukan menggunakan analisis faktor konfirmatori, uji validitas, uji reliabilitas, dan regresi linier. Exploratory factor analysis (Analisis Faktor Eksploratori) adalah model yang diaplikasikan untuk mengeksplorasi data yang ada mengenai jumlah karakteristiknya, sifat-sifat yang menarik, dan hubungan yang mungkin ada (Crowley \& Fan 1997). Tujuan utamanya adalah untuk mereduksi indikator-indikator menjadi suatu variabel. Untuk mencukupi dalam melakukan analisis exploratory factor analysis perlu terlebih dahulu dilakukan penilaian dengan uji KMO (Kaiser-Meyer-Olkin) pada data yang sudah diambil.

Uji Validitas merupakan suatu uji yang bertujuan untuk menentukan kemampuan (ketepatan) suatu indikator dalam mengukur variabel. Tingkat validitas indikator atau variabel manifest dalam mengukur variabel ditunjukan oleh besarnya loading ( $\lambda$ ). Loading factor merupakan korelasi antara variabel dengan faktor. Uji Reliabilitas adalah istilah yang dipakai untuk menunjukkan sejauh mana suatu hasil pengukuran relatif konsisten apabila alat ukur digunakan berulang kali (Umar 2002). Dalam penelitian ini pengujian reliabilitas menggunakan Cronbach's alpha.

Regresi linier adalah hubungan secara linear antara dua atau lebih variabel independen $\left(\mathrm{X}_{1}, \mathrm{X}_{2}, \ldots \mathrm{X}_{\mathrm{n}}\right)$ dengan variabel dependen $(\mathrm{Y})$. Analisis ini untuk mengetahui arah hubungan antara variabel independen dengan variabel dependen apakah masing-masing 
variabel independen berhubungan positif atau negatif dan untuk memprediksi nilai dari variabel dependen apabila nilai variabel independen mengalami kenaikan atau penurunan (Gujarati \& Porter 2009).

\section{ANALISIS DATA}

Penelitian diawali dengan melakukan pre-test kepada 30 orang responden dengan latar belakang profesi sebagai kontraktor, developer, arsitek, teknisi sipil, desain interior dan profesi sejenis. Pre-test yang dilakukan berupa pengisian kuesioner yang terdapat dalam sebuah platform Google-form.

Pada tahap penelitian, dilakukan penyebaran kuesioner kepada 100 orang responden dengan berbagai latar belakang usia, lama responden bekerja, profesi, lokasi perusahaan, dan proyek bisnis yang dilakukan responden.. Penelitian dilakukan selama Bulan Oktober 2017 Januari 2018 dan melakukan penyebaran kuesioner untuk mendapatkan data dan diolah menjadi sebuah informasi. Dari hasil penyebaran kuesioner responden diperoleh data sebagai berikut:

Tabel 4.1. Data Responden

\begin{tabular}{|c|c|c|}
\hline \multicolumn{2}{|c|}{ Latar Belakang Responden } & Persentase Pemilih \\
\hline \multirow{3}{*}{ Usia } & 21 - 30 Tahun & $86 \%$ \\
\hline & 31 - 40 Tahun & $12 \%$ \\
\hline & Di Atas 40 Tahun & $2 \%$ \\
\hline \multirow{3}{*}{ Lama Bekerja } & $1-5$ Tahun & $76 \%$ \\
\hline & $6-10$ Tahun & $19 \%$ \\
\hline & Lebih Dari 10 Tahun & $5 \%$ \\
\hline \multirow{6}{*}{ Profesi } & Arsitek & $34 \%$ \\
\hline & Kontraktor & $20 \%$ \\
\hline & Teknisi Sipil & $14 \%$ \\
\hline & Desain Interior & $10 \%$ \\
\hline & Pengembang & $8 \%$ \\
\hline & Lainnya & $14 \%$ \\
\hline \multirow{5}{*}{ Lokasi Perusahaan } & DKI Jakarta & $51 \%$ \\
\hline & Surabaya & $14 \%$ \\
\hline & Bandung & $12 \%$ \\
\hline & Tangerang & $5 \%$ \\
\hline & Lainnya & $18 \%$ \\
\hline \multirow{4}{*}{ Proyek Bisnis } & Komersial / Kantor & $46 \%$ \\
\hline & Bangunan Residensial & $36 \%$ \\
\hline & Bangunan Institusional & $12 \%$ \\
\hline & Lainnya & $6 \%$ \\
\hline
\end{tabular}


Setelah memperoleh data yang berasal dari 100 responden, hasil dari kuesioner tersebut kemudian diolah menggunakan software SPSS untuk mereduksi sejumlah indikator asal yang jumlahnya banyak menjadi sejumlah variabel baru dan hubungan variabel-variabel tersebut dengan willingness to pay terhadap produk tersebut.

A. Hasil Analisis Faktor, Validitas, dan Reliabilitas

Pada exploratory factor analysis, peneliti menguji apakah data fit dengan model yang dibentuk sebelumnya atau tidak. Menurut Widarjono (2010), penelitian dapat dilanjutkan apabila nilai KMO melebihi 0,5. Nilai KMO (Kaiser-Meyer-Olkin) dari data penelitian ini adalah 0,717 sehingga dapat disimpulkan bahwa variabel yang ada pada penelitian ini termasuk dalam kategori middling (sedang) dan mencukupi untuk melakukan analisis exploratory factor analysis. Pada tahap awal, hasil dari matrix rotation factor sebagai berikut:

Tabel 4.2. Rotated Component Matrix

\begin{tabular}{|c|c|c|c|c|}
\hline \multirow{2}{*}{ No } & \multirow{2}{*}{ Indikator } & \multicolumn{3}{|c|}{ Component } \\
\cline { 2 - 5 } & & $\mathbf{1}$ & $\mathbf{2}$ & $\mathbf{3}$ \\
\hline 1 & Kualitas &, 876 &, 158 &, 184 \\
\hline 2 & Harga &, 638 &, 233 &, 005 \\
\hline 3 & Mudah dipasang &, 920 &, 144 &, 000 \\
\hline 4 & Tidak beracun &, 923 &, 076 &, 011 \\
\hline 5 & Daur ulang &, 179 &, 810 &, 176 \\
\hline 6 & Proses &, 123 &, 616 &, 199 \\
\hline 7 & Mengurangi degradasi &, 248 &, 794 &,- 003 \\
\hline 8 & Hemat energi &, 048 &, 828 &,- 144 \\
\hline 10 & &, 080 &,- 023 &, 680 \\
\hline & Sertifikasi SNI & &, 129 & \\
\hline & & & & \\
\hline & & & & \\
\hline & & & & \\
\hline
\end{tabular}


Vol.01, No. 2, 2018

\begin{tabular}{|c|l|l|l|l|}
\hline 11 & Kompetitor &,- 007 &, 090 &, 911 \\
\hline
\end{tabular}

Pada Tabel 4.2, peneliti menginterpretasikan berdasarkan tinjauan pustaka dan penelitian sebelumnya, indikator 1 sampai 4 menjadi satu faktor perseptual, indikator 5-8 menunjukkan satu faktor perseptual, dan indikator 9-11 menunjukkan satu faktor corporate environmental performance. Hasil dari exploratory factor analysis, validitas, dan realibilitas dengan SPSS sebagai berikut :

Tabel 4.3. Exploratory Factor Analysis, Validitas, dan Realibilitas

\begin{tabular}{|c|c|c|c|c|}
\hline No & Items & Loading & Alpha & $\boldsymbol{A V E}$ \\
\hline \multicolumn{5}{|c|}{ Faktor Kontekstual } \\
\hline 1 & $\begin{array}{l}\text { Produk partisi modular mempunyai kualitas } \\
\text { sesuai standar. }\end{array}$ & 0,88 & \multirow[t]{4}{*}{0,882} & \multirow[t]{4}{*}{0,723} \\
\hline 2 & $\begin{array}{l}\text { Produk partisi modular menawarkan harga } \\
\text { sesuai kualitas yang diberikan. }\end{array}$ & 0,64 & & \\
\hline 3 & $\begin{array}{l}\text { Produk partisi modular mudah untuk } \\
\text { dipasang. }\end{array}$ & 0,92 & & \\
\hline 4 & $\begin{array}{l}\text { Produk partisi modular menggunakan bahan } \\
\text { yang tidak beracun. }\end{array}$ & 0,93 & & \\
\hline \multicolumn{5}{|c|}{ Faktor Perseptual } \\
\hline 5 & $\begin{array}{l}\text { Pembelian produk partisi modular membantu } \\
\text { keberlanjutan sumber daya alam. }\end{array}$ & 0,81 & \multirow[t]{4}{*}{0,781} & \multirow[t]{4}{*}{0,592} \\
\hline 6 & $\begin{array}{l}\text { Saya memilih produk partisi modular karena } \\
\text { menggunakan material yang dalam proses } \\
\text { produksinya tidak mengeluarkan zat } \\
\text { berbahaya bagi lingkungan }\end{array}$ & 0,62 & & \\
\hline 7 & $\begin{array}{l}\text { Penggunaan produk partisi modular dapat } \\
\text { mengurangi degradasi lingkungan }\end{array}$ & 0,80 & & \\
\hline 8 & $\begin{array}{l}\text { Saya memilih produk partisi modular untuk } \\
\text { menghemat sumber daya dan energi }\end{array}$ & 0,83 & & \\
\hline \multicolumn{5}{|c|}{ Corporate Environmental Performance } \\
\hline 9 & $\begin{array}{l}\text { Saya memilih Mycotech karena produk yang } \\
\text { dihasilkan memiliki sertifikat SNI 03-6384- }\end{array}$ & 0,68 & 0,783 & 0,700 \\
\hline
\end{tabular}




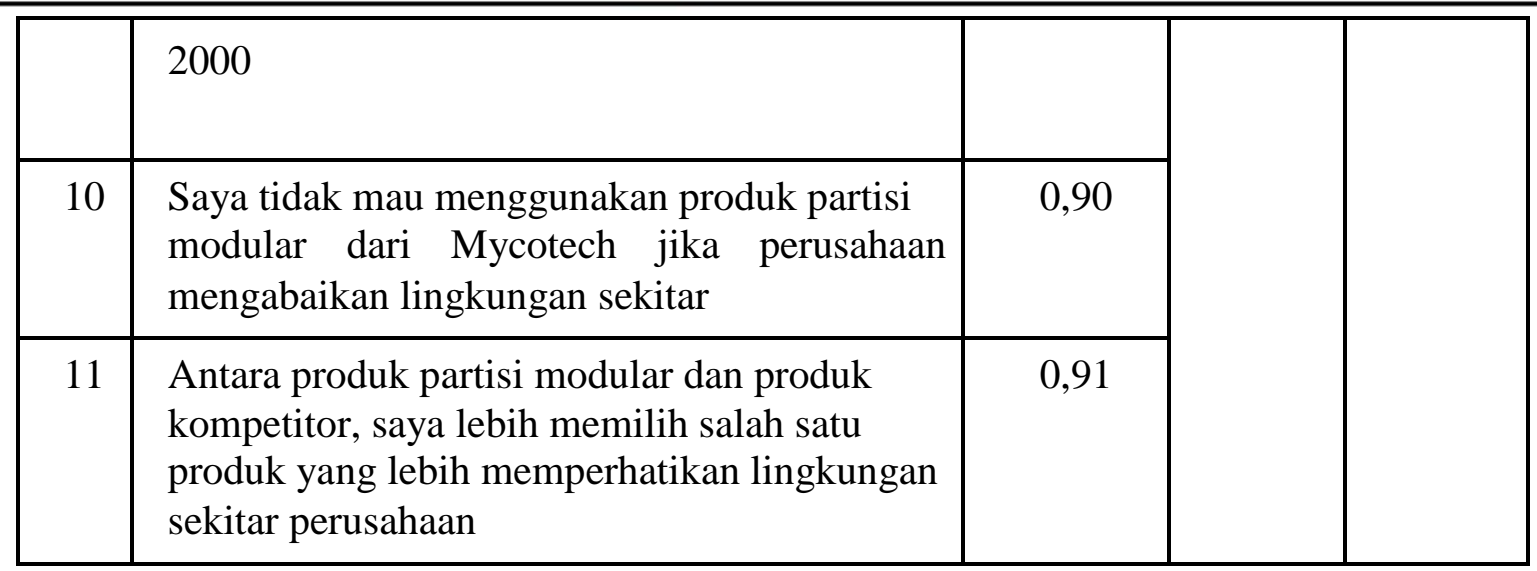

Makin besar loading factor $(\lambda)$ menunjukan indikasi bahwa variabel manifest makin valid sebagai instrumen pengukuran variabel. Menurut Hair et al. (2010, 777), angka minimal dari loading factor adalah $\geq 0,5$ atau idealnya $\geq 0,7$. Jika nilai loading factor $(\lambda)$ memenuhi nilai minimal, maka dapat disimpulkan bahwa data tersebut valid. Menurut Hair et al. (2007, 244), batas bawah untuk Cronbach's alpha adalah 0,70. Jika nilai Cronbach's alpha memenuhi, maka data reliabel.

Pada Tabel 4.3, ditunjukkan nilai loading dari indikator pada setiap variabel di atas 0,5 (Churchill, 1979) yang merupakan batas minimum. Hasil loading menunjukkan 4 indikator telah mewakili variabel faktor kontekstual, 4 indikator variabel faktor perseptual, dan 3 indikator variabel corporate environmental performance. Pengujian unidimensionalitas 11 indikator menggunakan rotasi varimax menunjukkan nilai 69,998\% yang artinya 69,998\% dari 11 indikator mewakili tiap variabel secara tepat.

Berdasarkan hasil analisis, dapat diketahui bahwa tiga variabel mempunyai nilai realibilitas tinggi (Alpha > 0,7) yang artinya setiap indikator telah mewakili satu variabel. Hasil dari AVE (Average Variance Extracted) menunjukkan nilai di atas 0,5 yang artinya memenuhi validitas diskriminan. Validitas konvergen dapat diukur melalui muatan silang (cross loading). Nilai dari loading tiap variabel yang diukur lebih tinggi dibanding dengan variabel faktor yang tidak diukur. Pada Tabel 4.3 ditunjukkan semua indikator sesuai variabel reliabilitas tinggi, validitas konvergen dan diskriminan diterima.

\section{B. Hasil Analisis Regresi Linier}

Analisis regresi linier dengan faktor kontekstual, faktor perseptual, dan corporate environmental performance sebagai variabel independen terhadap kesediaan untuk membayar sebagai variabel dependen didasarkan pada Tabel 4.4 di bawah ini: 
Tabel 4.4. Hasil Analisis Regresi Linier

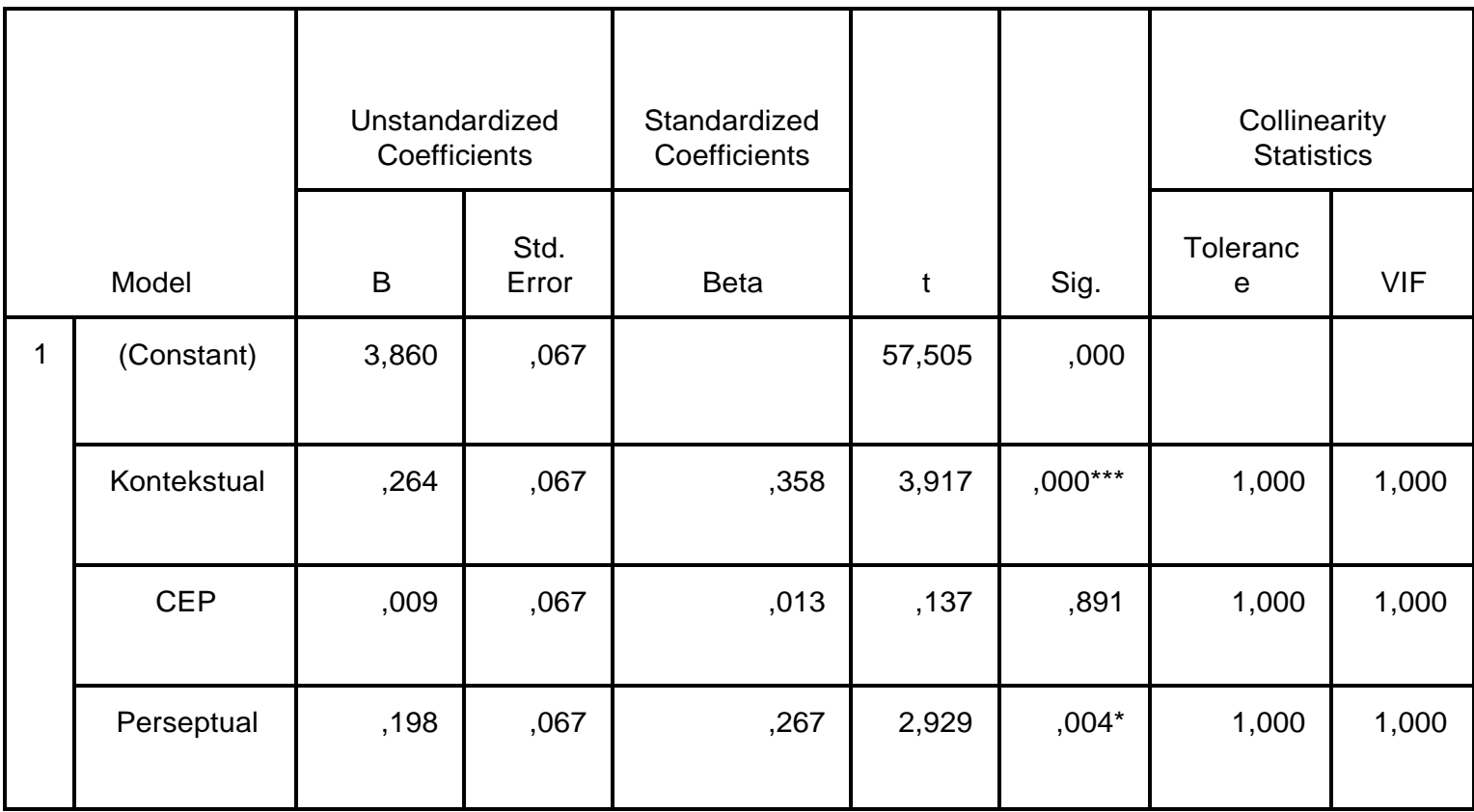

a. Dependent Variable: WTP

*** : p-value- atau nilai signifikan $<0,001$

* : p-value- atau nilai signifikan $<0,05$

Hubungan antar variabel dependen dengan independen memiliki hubungan positif apabila memiliki nilai signifikansi kurang dari 0,05. Hal ini memiliki makna bahwa variabel independen mempengaruhi variabel dependen.

Rumus persamaan regresi linier adalah $\mathrm{y}=3,860+0,264 \mathrm{X} 1+0,198 \mathrm{X} 2$. Angka koefisien regresi menunjukkan setiap penambahan $1 \%$ faktor kontekstual dan perseptual, maka kesediaan responden untuk membayar akan meningkat sebesar 0,264 dan 0,198. Pada Tabel 4.3, ditunjukkan faktor kontekstual dan faktor perseptual dengan nilai signifikan $<0,05$ mempengaruhi kesediaan responden untuk membayar. Tetapi, corporate environmental performance tidak mempengaruhi kesediaan responden untuk membayar yang artinya responden kurang sadar dan tertarik pada performa perusahaan yang lebih baik terhadap lingkungan maupun keberlanjutan perusahaan.

Nilai VIF (Variance Inflation Factor) di bawah 2 yang artinya tidak terjadi relasi (multikolonieritas) di antara variabel independen. Hasil dari analisis regresi menunjukkan faktor kontekstual dan faktor perseptual mempengaruhi kesediaan responden untuk membayar, sedangkan corporate environmental performance tidak mempengaruhi kesediaan responden untuk membayar. Hasil signifikansi yang paling rendah $(0,000)$ menunjukkan faktor kontekstual yang paling berhubungan dengan kesediaan responden untuk membayar. 


\section{KESIMPULAN}

Penelitian ini menguji indikator-indikator yang sudah dikelompokkan berdasarkan variabel yang konsisten berada dalam pengelompokan tersebut atau tidak dan hubungan variabel-variabel tersebut dengan willingness to pay terhadap produk tersebut oleh konsumen. Hasil dari regresi linier menunjukkan faktor kontekstual dan perseptual mempengaruhi kesediaan responden untuk membayar produk. Indikator-indikator dalam setiap faktor kontekstual dan perseptual dapat dimanfaatkan perusahaan dalam memasarkan produk. Corporate Environmental Performance dapat meningkatkan kesadaran perusahaan yang pada akhirnya akan mengarah ke masa depan yang sejahtera untuk industri-industri dan produk perusahaan untuk memenangkan persaingan. Corporate Environmental Performance menunjukkan hasil regresi tidak mempengaruhi kesediaan konsumen untuk membayar produk tersebut. Hasil ini membutuhkan penelitian lebih lanjut apakah Corporate Environmental Performance sudah menjadi aspek yang dipertimbangkan sebagai standar dari perusahaan dalam membuat produk yang akan dipasarkan ke depannya.

Hasil penelitian ini dapat dimanfaatkan untuk penelitian terhadap produk sejenis dan dapat diteliti lebih lanjut dengan subjek dan objek yang berbeda. Masih banyak faktor-faktor dan indikator yang dapat diuji untuk mengetahui kesediaan responden untuk membayar. Faktor kontekstual dan faktor perseptual seperti persepsi individu, kepercayaan, komitmen perilaku, kualitas standar, nilai ekonomis, dan karakteristik produk mempengaruhi kesediaan responden untuk membayar produk ramah lingkungan. Hal ini dapat dimanfaatkan perusahaan dengan industri sejenis dalam memasarkan produknya.

\section{DAFTAR PUSTAKA}

A. Biswas dan M. Roy. (2015). "Green products: An exploratory study on the consumer behaviour in emerging economies of the East", Journal of Cleaner Production, 87: 463-468.

Biswas, Aindrila. (2016). "A Study of Consumers' Willingness to Pay for Green Products”, Journal of Advanced Management Science, 4, No. 3: 211-215.

Churchill, Gilbert A. (1979). “A Paradigm for Developing Better Measures for Marketing Constructs", Journal of Marketing Research, 16, No. 1: 64-73.

Crowley, S. L., dan Fan X. (1997). "Structural Equation Modeling: Basic Concepts and Applications in Personality Assessment Research", Journal of Personality Assessment, 68, No. 3: 508-531.

C. Seguin, L. G. Pelletier, and J. Hunsley. (1998). "Toward a model of environmental activism," Environment and Behavior, 30: 628-652. 
Damodar N., Gujarati dan Dawn C. Porter. (2009). Basic Econometric. 5th Edition. McGraw -Hill: New York.

Ferro et al. (2009). Handbook of Research on Overcoming Digital Divides: Constructing an Equitable and Competitive Information Society, pp.630-644. Information Science Reference : New York.

Green, S.B. (1991). "How Many Subjects Does It Take To Do a Regression Analysis?”, Multivariate Behavioral Research, 26, No. 3: 499-510.

Hair et al. (2010). Multivariate Data Analysis. Seventh Edition. Pearson Prentice Hall. ISO 14031. (2013). Environmental Management - Environmental Performance Evaluation.

Kaiser, H. F. (1970). “A second Generation Little Jiffy”, Psychometrika, 35, No. 4: 4017415.

Konstruksi Dalam Angka 2017. Volume 6. Badan Pusat Statistik. Jakarta. 2017.

Li, T. dan Meshkova, Z. (2013). "Examining the Impact of Rich Media on Consumer Willingness to Pay in Online Stores". Electronic Commerce Research and Applications, 12, No. 6: 449-461.

Mohr, L.A. dan Webb, D.J. (2005). “Corporate Reputation: What Do Consumers Really Care About?", Journal of Advertising Research, 45, No. 3: 305-313.

Pelsmacker, Patrick De et al. (2005). "Do Consumers Care about Ethics? Willingness to Pay for Fair-Trade Coffee”. The Journal of Consumer Affairs, 39, No. 2: 363-385.

Rodrigues, Paula dan Borges, A.P. (2015). "Corporate social responsibility and its impact in consumer decision-making", Social Responsibility Journal, 11, No. 4: 690701.

Sugiyono. (2013). Metode penelitian bisnis kuantitatif, kualitatif dan R\&D. Bandung : Alfabeta.

The Global Competitiveness Report 2017-2018, World Economic Forum, Geneva, 2017.

Umar, H. (2002). Metode riset komunikasi organisasi. Jakarta: PT. Gramedia Pustaka Utama. Widarjono, A. (2010). Analisis Statistika Multivariat Terapan. Yogyakarta : Unit Penerbit dan Percetakan Sekolah Tinggi Ilmu Manajemen YKPN.

X. Liu, C. Wang et al. (2010). "Sustainable Consumption: Green Purchasing Behaviours of Urban Residents in China”, Sustainable Development, 20, No. 4: 293-308. 


\section{LAMPIRAN}

\section{Lampiran 1. Pertanyaan Kuesioner}

Kepada responden yang terhormat,

Kami mahasiswa Universitas Prasetiya Mulya angkatan MMR 55 meminta waktu Anda untuk mengisi beberapa tahap kuesioner untuk membantu penyelesaian mata kuliah fieldwork project. Kami melakukan penelitian tentang Kesediaan Konsumen untuk Membayar Produk Partisi Modular pada PT. Miko Bahtera Nusantara atau yang biasa disebut dengan Mycotech.

Mycotech adalah perusahaan yang bergerak dalam bidang pembuatan material bahan bangunan ramah lingkungan dengan memanfaatkan limbah pertanian tanaman berserat dan bibit miselium jamur sebagai bahan baku utama. Berikut adalah situs utama perusahaan https://www.mycote.ch/

Sebagai contoh, perusahaan berhasil membuat substitusi batu bata menggunakan bahan baku yang sudah disebutkan diatas. Berikut contoh produk jadi yang sudah pernah diproduksi oleh Mycotech:

\section{https://www.youtube.com/watch?v=HcSgOzwdIso}

Kuesioner ini dibagi menjadi 3 bagian dengan jawaban menggunakan skala likert nilai 1 Sangat Tidak Setuju dan 5 Sangat Setuju dan 1 bagian memilih jawaban yang paling tepat.

\section{Keterangan}

$\begin{array}{llll}\text { STS } & \text { : Sangat Tidak Setuju } & \text { S } & \text { : Setuju } \\ \text { TS } & : \text { Tidak Setuju } & \text { SS } & \text { : Sangat Setuju } \\ \text { N } & : \text { Netral } & & \end{array}$

\begin{tabular}{|l|l|l|l|l|l|l|}
\hline No & Pernyataan & STS & TS & N & S & SS \\
\hline 1. & Produk partisi modular mempunyai kualitas sesuai standar. & & & & & \\
\hline 2. & $\begin{array}{l}\text { Produk partisi modular menawarkan harga sesuai kualitas } \\
\text { yang diberikan. }\end{array}$ & & & & & \\
\hline 3. & Produk partisi modular mudah untuk dipasang. & & & & & \\
\hline 4. & Produk partisi modular menggunakan bahan yang tidak & & & & & \\
\hline
\end{tabular}




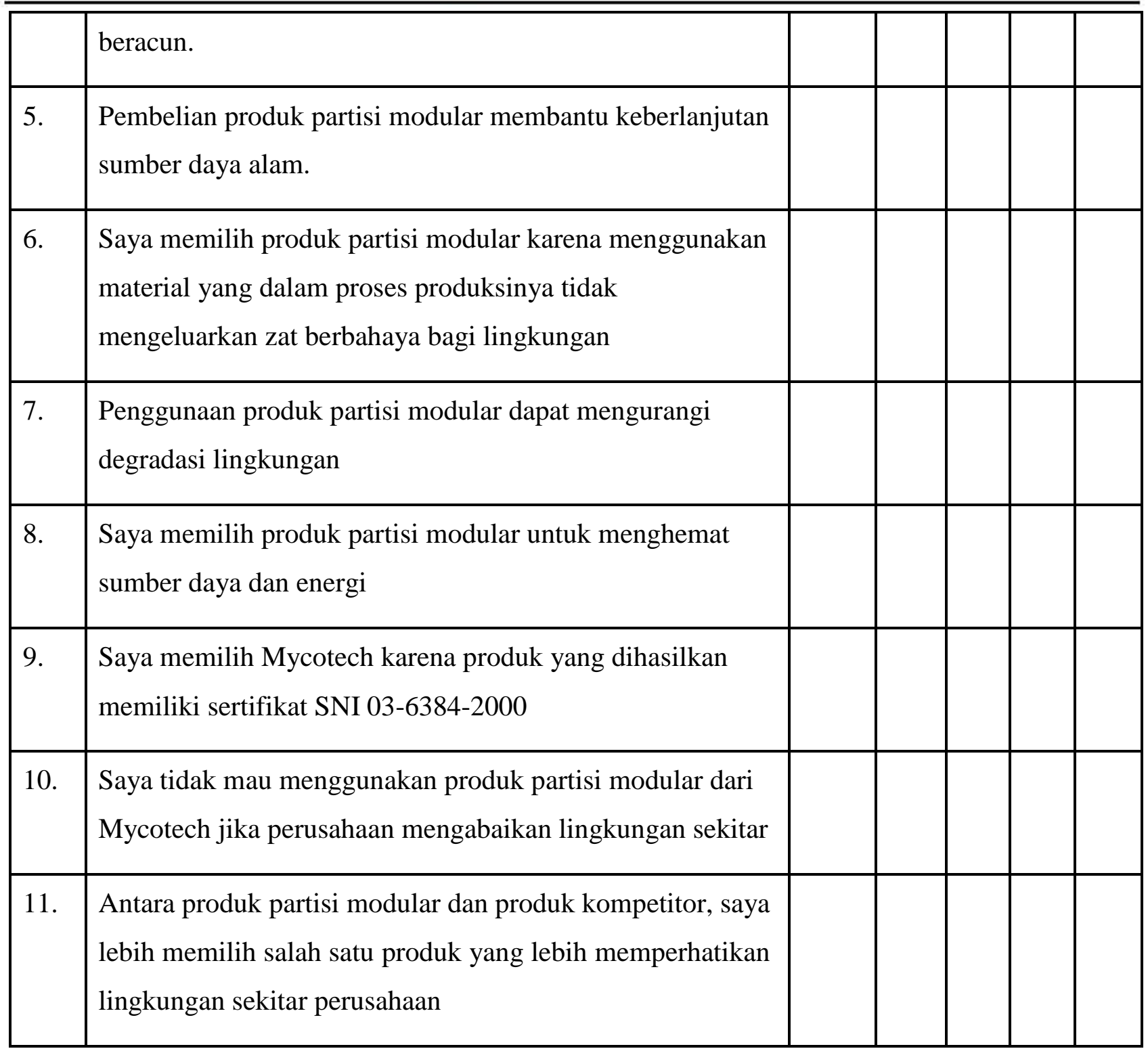

12 Dari keseluruhan spesifikasi, harga dan gambaran produk yang sudah dipaparkan sebelumnya, Saya bersedia untuk membayar produk partisi modular ini untuk proyek-proyek yang akan dijalani perusahaan

\section{Bagian 2 : Demografi Responden}

Berilah tanda $(\mathrm{x})$ pada kolom jawaban yang paling tepat yang tersedia di bawah.

13. Bisnis utama perusahaan responden?

7 Arsitek 
7 Konsultan

7 Konstruksi

7 Pengembang

7 Desain Interior

7 Lainnya...

14. Lokasi perusahaan responden?

7 DKI Jakarta

7 Bandung

7 Tangerang

7 Bekasi

15. Projek yang dilaksanakan oleh perusahaan responden

7 Bangunan residensial

7 Bangunan institusional

7 Komersial / kantor

7 Industrial

7 Pekerjaan sipil

7 Lainnya...

16. Berapa tahun responden bekerja di perusahaan?

70 - 5 tahun

76 - 10 tahun

711 - 15 tahun

7 Lebih dari 16 tahun

17. Berapakah usia Anda?

7 20-30 tahun

7 31-40 tahun

7 41-50 tahun

$7>50$ tahun

Terima Kasih 
Vol.01, No. 2, 2018

\section{Lampiran 2. Data Kuesioner}

\begin{tabular}{|c|c|c|c|c|c|c|c|c|c|c|c|c|}
\hline & $\begin{array}{l}\text { No } \\
1\end{array}$ & $\begin{array}{l}\text { No } \\
2\end{array}$ & $\begin{array}{l}\text { No } \\
3\end{array}$ & $\begin{array}{l}\text { No } \\
4\end{array}$ & $\begin{array}{l}\text { No } \\
5\end{array}$ & $\begin{array}{l}\text { No } \\
6\end{array}$ & $\begin{array}{l}\text { No } \\
7\end{array}$ & $\begin{array}{l}\text { No } \\
8\end{array}$ & No 9 & $\begin{array}{l}\text { No } \\
10\end{array}$ & $\begin{array}{l}\text { No } \\
11\end{array}$ & $\begin{array}{l}\text { No } \\
12\end{array}$ \\
\hline Orang 1 & 5 & 5 & 5 & 5 & 5 & 5 & 5 & 3 & 5 & 4 & 4 & 4 \\
\hline Orang 2 & 5 & 4 & 5 & 5 & 4 & 4 & 4 & 4 & 4 & 4 & 4 & 4 \\
\hline Orang 3 & 4 & 3 & 4 & 4 & 3 & 4 & 3 & 2 & 5 & 5 & 5 & 3 \\
\hline Orang 4 & 4 & 2 & 2 & 4 & 3 & 3 & 3 & 1 & 4 & 4 & 4 & 4 \\
\hline Orang 5 & 3 & 3 & 3 & 3 & 4 & 4 & 4 & 4 & 2 & 4 & 4 & 3 \\
\hline Orang 6 & 3 & 3 & 2 & 3 & 4 & 4 & 4 & 4 & 5 & 4 & 4 & 5 \\
\hline Orang 7 & 3 & 3 & 3 & 3 & 4 & 3 & 4 & 4 & 4 & 2 & 3 & 4 \\
\hline Orang 8 & 3 & 4 & 3 & 3 & 4 & 4 & 4 & 4 & 3 & 3 & 3 & 3 \\
\hline Orang 9 & 4 & 3 & 4 & 4 & 5 & 4 & 4 & 4 & 4 & 4 & 4 & 5 \\
\hline Orang 10 & 4 & 4 & 4 & 4 & 4 & 4 & 3 & 3 & 5 & 5 & 5 & 3 \\
\hline Orang 11 & 3 & 3 & 3 & 3 & 4 & 5 & 4 & 5 & 2 & 3 & 3 & 4 \\
\hline Orang 12 & 5 & 5 & 5 & 5 & 5 & 5 & 5 & 5 & 3 & 5 & 5 & 4 \\
\hline Orang 13 & 5 & 5 & 5 & 5 & 5 & 5 & 5 & 4 & 5 & 5 & 5 & 5 \\
\hline Orang 14 & 3 & 4 & 3 & 3 & 3 & 3 & 4 & 4 & 5 & 4 & 4 & 3 \\
\hline Orang 15 & 4 & 4 & 5 & 4 & 4 & 4 & 5 & 4 & 4 & 5 & 5 & 4 \\
\hline Orang 16 & 4 & 4 & 5 & 4 & 3 & 3 & 4 & 4 & 4 & 4 & 4 & 3 \\
\hline Orang 17 & 4 & 4 & 5 & 4 & 5 & 4 & 4 & 4 & 3 & 4 & 4 & 3 \\
\hline Orang 18 & 4 & 3 & 3 & 3 & 5 & 5 & 5 & 4 & 5 & 4 & 4 & 5 \\
\hline
\end{tabular}


Vol.01, No. 2, 2018

\begin{tabular}{|c|c|c|c|c|c|c|c|c|c|c|c|c|}
\hline Orang 19 & 5 & 5 & 3 & 3 & 5 & 5 & 5 & 4 & 5 & 5 & 5 & 2 \\
\hline Orang 20 & 4 & 5 & 4 & 3 & 5 & 4 & 4 & 4 & 5 & 5 & 5 & 4 \\
\hline Orang 21 & 5 & 4 & 5 & 5 & 5 & 4 & 4 & 4 & 5 & 5 & 5 & 3 \\
\hline Orang 22 & 5 & 5 & 4 & 4 & 4 & 5 & 4 & 3 & 4 & 3 & 4 & 1 \\
\hline Orang 23 & 5 & 5 & 5 & 5 & 5 & 5 & 4 & 5 & 5 & 4 & 4 & 5 \\
\hline Orang 24 & 5 & 4 & 5 & 5 & 4 & 3 & 4 & 3 & 4 & 3 & 3 & 4 \\
\hline Orang 25 & 4 & 4 & 4 & 4 & 4 & 3 & 4 & 4 & 4 & 4 & 4 & 4 \\
\hline Orang 26 & 5 & 5 & 5 & 5 & 4 & 4 & 4 & 4 & 4 & 5 & 5 & 4 \\
\hline Orang 27 & 4 & 4 & 4 & 4 & 4 & 4 & 4 & 4 & 4 & 4 & 4 & 3 \\
\hline Orang 28 & 5 & 5 & 5 & 5 & 4 & 4 & 4 & 3 & 5 & 4 & 4 & 4 \\
\hline Orang 29 & 5 & 4 & 4 & 5 & 5 & 4 & 5 & 5 & 5 & 5 & 5 & 4 \\
\hline Orang 30 & 5 & 5 & 5 & 5 & 4 & 5 & 4 & 4 & 3 & 3 & 3 & 4 \\
\hline Orang 31 & 4 & 4 & 4 & 4 & 4 & 4 & 3 & 3 & 3 & 4 & 3 & 2 \\
\hline Orang 32 & 5 & 5 & 5 & 5 & 5 & 5 & 5 & 5 & 4 & 5 & 3 & 4 \\
\hline Orang 33 & 5 & 5 & 5 & 5 & 4 & 3 & 4 & 4 & 4 & 4 & 3 & 2 \\
\hline Orang 34 & 5 & 4 & 5 & 5 & 4 & 5 & 4 & 4 & 4 & 4 & 4 & 4 \\
\hline Orang 35 & 5 & 4 & 5 & 5 & 5 & 4 & 4 & 5 & 4 & 4 & 4 & 5 \\
\hline Orang 36 & 5 & 4 & 5 & 5 & 4 & 4 & 5 & 4 & 3 & 4 & 4 & 4 \\
\hline Orang 37 & 4 & 4 & 4 & 4 & 4 & 4 & 4 & 4 & 4 & 3 & 5 & 4 \\
\hline
\end{tabular}


Vol.01, No. 2, 2018

\begin{tabular}{|c|c|c|c|c|c|c|c|c|c|c|c|c|}
\hline Orang 38 & 3 & 3 & 3 & 3 & 4 & 5 & 3 & 3 & 5 & 5 & 5 & 3 \\
\hline Orang 39 & 4 & 5 & 4 & 4 & 5 & 5 & 5 & 5 & 4 & 4 & 4 & 4 \\
\hline Orang 40 & 5 & 4 & 5 & 5 & 5 & 4 & 5 & 5 & 5 & 3 & 3 & 4 \\
\hline Orang 41 & 4 & 5 & 4 & 4 & 5 & 3 & 4 & 4 & 4 & 3 & 5 & 3 \\
\hline Orang 42 & 3 & 3 & 3 & 3 & 5 & 5 & 5 & 5 & 5 & 5 & 5 & 4 \\
\hline Orang 43 & 5 & 5 & 5 & 5 & 3 & 5 & 4 & 3 & 5 & 5 & 5 & 3 \\
\hline Orang 44 & 5 & 2 & 5 & 5 & 4 & 5 & 4 & 5 & 4 & 4 & 4 & 5 \\
\hline Orang 45 & 5 & 4 & 5 & 5 & 4 & 4 & 4 & 4 & 5 & 4 & 5 & 4 \\
\hline Orang 46 & 3 & 4 & 3 & 3 & 4 & 3 & 3 & 4 & 5 & 5 & 5 & 3 \\
\hline Orang 47 & 5 & 4 & 5 & 5 & 4 & 4 & 3 & 3 & 4 & 4 & 4 & 4 \\
\hline Orang 48 & 5 & 5 & 5 & 5 & 5 & 5 & 5 & 5 & 5 & 5 & 5 & 4 \\
\hline Orang 49 & 4 & 3 & 3 & 4 & 4 & 4 & 3 & 4 & 5 & 4 & 4 & 2 \\
\hline Orang 50 & 5 & 4 & 5 & 5 & 5 & 5 & 5 & 5 & 4 & 5 & 5 & 5 \\
\hline Orang 51 & 4 & 4 & 4 & 4 & 5 & 5 & 5 & 4 & 4 & 5 & 5 & 5 \\
\hline Orang 52 & 5 & 4 & 5 & 5 & 5 & 4 & 5 & 5 & 5 & 4 & 4 & 5 \\
\hline Orang 53 & 3 & 3 & 3 & 3 & 4 & 4 & 4 & 4 & 3 & 4 & 4 & 4 \\
\hline Orang 54 & 4 & 4 & 4 & 4 & 5 & 5 & 4 & 4 & 5 & 4 & 4 & 4 \\
\hline Orang 55 & 5 & 5 & 5 & 5 & 5 & 4 & 4 & 5 & 5 & 5 & 5 & 3 \\
\hline Orang 56 & 4 & 4 & 4 & 4 & 5 & 5 & 4 & 4 & 5 & 5 & 5 & 4 \\
\hline
\end{tabular}


Vol.01, No. 2, 2018

\begin{tabular}{|c|c|c|c|c|c|c|c|c|c|c|c|c|}
\hline Orang 57 & 5 & 3 & 5 & 5 & 5 & 4 & 4 & 4 & 5 & 5 & 5 & 5 \\
\hline Orang 58 & 4 & 4 & 4 & 4 & 4 & 5 & 4 & 4 & 5 & 4 & 4 & 4 \\
\hline Orang 59 & 5 & 4 & 5 & 5 & 4 & 4 & 5 & 4 & 4 & 4 & 4 & 4 \\
\hline Orang 60 & 5 & 5 & 5 & 5 & 5 & 5 & 5 & 3 & 5 & 4 & 4 & 3 \\
\hline Orang 61 & 5 & 4 & 5 & 5 & 4 & 4 & 4 & 4 & 4 & 4 & 4 & 4 \\
\hline Orang 62 & 4 & 4 & 4 & 4 & 3 & 4 & 3 & 2 & 5 & 5 & 5 & 3 \\
\hline Orang 63 & 4 & 4 & 4 & 4 & 3 & 3 & 3 & 1 & 4 & 4 & 4 & 3 \\
\hline Orang 64 & 3 & 4 & 3 & 3 & 4 & 4 & 4 & 4 & 2 & 4 & 4 & 4 \\
\hline Orang 65 & 3 & 4 & 3 & 3 & 4 & 4 & 4 & 4 & 5 & 4 & 4 & 4 \\
\hline Orang 66 & 3 & 4 & 4 & 5 & 4 & 3 & 4 & 4 & 4 & 2 & 2 & 3 \\
\hline Orang 67 & 3 & 4 & 3 & 3 & 4 & 4 & 4 & 4 & 3 & 3 & 3 & 2 \\
\hline Orang 68 & 4 & 3 & 4 & 4 & 5 & 4 & 4 & 4 & 4 & 4 & 4 & 4 \\
\hline Orang 69 & 4 & 4 & 4 & 4 & 4 & 4 & 3 & 3 & 5 & 5 & 5 & 4 \\
\hline Orang 70 & 3 & 4 & 4 & 3 & 4 & 5 & 4 & 5 & 2 & 3 & 3 & 2 \\
\hline Orang 71 & 5 & 5 & 5 & 5 & 5 & 5 & 5 & 5 & 3 & 5 & 5 & 5 \\
\hline Orang 72 & 5 & 5 & 5 & 5 & 5 & 5 & 5 & 4 & 5 & 5 & 5 & 5 \\
\hline Orang 73 & 3 & 4 & 2 & 2 & 3 & 3 & 4 & 4 & 5 & 4 & 4 & 4 \\
\hline Orang 74 & 4 & 4 & 4 & 4 & 4 & 4 & 5 & 4 & 4 & 5 & 5 & 4 \\
\hline Orang 75 & 4 & 4 & 4 & 4 & 3 & 3 & 4 & 4 & 4 & 4 & 4 & 4 \\
\hline
\end{tabular}


Vol.01, No. 2, 2018

\begin{tabular}{|c|c|c|c|c|c|c|c|c|c|c|c|c|}
\hline Orang 76 & 4 & 4 & 4 & 4 & 5 & 4 & 4 & 4 & 3 & 4 & 4 & 4 \\
\hline Orang 77 & 4 & 4 & 4 & 5 & 5 & 5 & 5 & 4 & 5 & 4 & 4 & 4 \\
\hline Orang 78 & 5 & 5 & 5 & 5 & 5 & 5 & 5 & 4 & 5 & 5 & 5 & 5 \\
\hline Orang 79 & 4 & 5 & 4 & 4 & 5 & 4 & 4 & 4 & 5 & 5 & 5 & 3 \\
\hline Orang 80 & 5 & 4 & 3 & 3 & 5 & 4 & 4 & 4 & 5 & 5 & 5 & 4 \\
\hline Orang 81 & 5 & 5 & 3 & 3 & 4 & 5 & 4 & 3 & 4 & 3 & 3 & 3 \\
\hline Orang 82 & 5 & 5 & 5 & 5 & 5 & 5 & 4 & 5 & 5 & 4 & 4 & 4 \\
\hline Orang 83 & 5 & 5 & 5 & 5 & 4 & 5 & 4 & 3 & 4 & 3 & 3 & 3 \\
\hline Orang 84 & 4 & 4 & 4 & 4 & 4 & 5 & 4 & 4 & 4 & 4 & 4 & 4 \\
\hline Orang 85 & 5 & 5 & 5 & 5 & 4 & 4 & 4 & 4 & 4 & 5 & 5 & 4 \\
\hline Orang 86 & 4 & 4 & 3 & 3 & 4 & 4 & 4 & 4 & 4 & 4 & 4 & 4 \\
\hline Orang 87 & 5 & 5 & 3 & 3 & 4 & 4 & 4 & 3 & 5 & 4 & 4 & 4 \\
\hline Orang 88 & 5 & 4 & 3 & 3 & 5 & 5 & 5 & 5 & 5 & 5 & 5 & 5 \\
\hline Orang 89 & 5 & 5 & 5 & 5 & 4 & 4 & 4 & 4 & 3 & 3 & 3 & 3 \\
\hline Orang 90 & 4 & 4 & 4 & 4 & 4 & 4 & 3 & 3 & 3 & 4 & 4 & 4 \\
\hline Orang 91 & 5 & 5 & 5 & 5 & 5 & 5 & 5 & 5 & 4 & 5 & 5 & 5 \\
\hline Orang 92 & 5 & 5 & 5 & 5 & 4 & 4 & 4 & 4 & 4 & 4 & 4 & 4 \\
\hline Orang 93 & 5 & 5 & 5 & 5 & 4 & 5 & 4 & 4 & 4 & 4 & 4 & 4 \\
\hline Orang 94 & 5 & 5 & 5 & 5 & 5 & 4 & 4 & 5 & 4 & 4 & 4 & 4 \\
\hline
\end{tabular}


Vol.01, No. 2, 2018

\begin{tabular}{|l|l|l|l|l|l|l|l|l|l|l|l|l|}
\hline Orang 95 & 5 & 5 & 5 & 5 & 4 & 4 & 5 & 4 & 3 & 4 & 4 & 4 \\
\hline Orang 96 & 4 & 4 & 4 & 4 & 4 & 4 & 4 & 4 & 4 & 3 & 3 & 3 \\
\hline Orang 97 & 3 & 3 & 3 & 3 & 4 & 5 & 3 & 3 & 5 & 5 & 5 & 4 \\
\hline Orang 98 & 4 & 4 & 4 & 4 & 5 & 5 & 5 & 5 & 4 & 4 & 4 & 5 \\
\hline Orang 99 & 5 & 5 & 5 & 5 & 5 & 4 & 5 & 5 & 5 & 3 & 3 & 4 \\
\hline Orang 100 & 4 & 5 & 4 & 4 & 5 & 5 & 4 & 4 & 4 & 3 & 3 & 4 \\
\hline
\end{tabular}

\section{Lampiran 3. Hasil SPSS}

KMO and Bartlett's Test

\begin{tabular}{|l|r|}
\hline Kaiser-Meyer-Olkin Measure of Sampling Adequacy. &, 717 \\
Bartlett's Test of Sphericity $\quad$ Approx. Chi-Square & 605,228 \\
& df \\
Sig. & 55 \\
&, 000 \\
\hline
\end{tabular}

\begin{tabular}{|r|r|r|r|}
\hline Kontekstual & \multicolumn{1}{|l|}{ CEP } & Perseptual & WTP \\
\hline 119,815 & $-18,178$ & $-38,559$ & 4 \\
\hline 32,028 & $-61,518$ & $-87,534$ & 4 \\
\hline$-120,561$ & 150,986 & $-213,627$ & 3 \\
\hline$-255,195$ & 55,156 & $-193,435$ & 5 \\
\hline$-15,422$ & $-27,164$ & 131,982 & 3 \\
\hline$-155,526$ & 95,326 & 110,931 & 3 \\
\hline$-194,631$ & $-127,942$ & 99,274 & 4 \\
\hline$-147,909$ & $-113,486$ & 124,646 & 3 \\
\hline$-37,421$ & 6,582 & 59,602 & 4 \\
\hline$-55,653$ & 138,507 & $-131,303$ & 3 \\
\hline$-141,472$ & $-130,827$ & 234,111 & 4 \\
\hline 159,634 & 415 & 68,483 & \\
\hline
\end{tabular}


Vol.01, No. 2, 2018

\begin{tabular}{|c|c|c|c|}
\hline 158,551 & 81,452 & $-11,219$ & 5 \\
\hline$-157,324$ & 43,246 & $-7,067$ & 3 \\
\hline 30,848 & 67,511 & -359 & 4 \\
\hline$-6,645$ & $-54,572$ & $-105,063$ & 4 \\
\hline 48 & $-60,159$ & 3,661 & 4 \\
\hline$-29,768$ & 83,507 & 180,221 & 4 \\
\hline 64,809 & 153,979 & 103,148 & 5 \\
\hline 13,117 & 139,061 & 28,697 & 4 \\
\hline 89,543 & 89,627 & $-77,575$ & 3 \\
\hline$-1,374$ & $-72,693$ & $-48,558$ & 2 \\
\hline 124,145 & $-28,011$ & 1,182 & 5 \\
\hline$-26,547$ & $-172,273$ & $-147,558$ & 4 \\
\hline$-62,637$ & $-27,591$ & $-32,482$ & 4 \\
\hline 76,796 & 31,716 & $-121,321$ & 4 \\
\hline$-42,798$ & $-16,467$ & 202 & 3 \\
\hline 4,543 & $-33,052$ & $-164,315$ & 4 \\
\hline 109,265 & 94,629 & 43,136 & 3 \\
\hline 43,436 & $-206,439$ & $-30,876$ & 5 \\
\hline$-103,821$ & $-93,467$ & $-68,121$ & 3 \\
\hline 145,977 & $-71,072$ & 74,465 & 4 \\
\hline 23,531 & $-141,659$ & $-122,134$ & 2 \\
\hline 51,866 & $-50,394$ & $-5,485$ & 4 \\
\hline 75,082 & $-60,022$ & 7,524 & 5 \\
\hline 51,974 & $-101,704$ & $-25,474$ & 4 \\
\hline$-44,685$ & $-13,592$ & -383 & 4 \\
\hline$-132,496$ & 208,657 & 1,852 & 3 \\
\hline
\end{tabular}


Vol.01, No. 2, 2018

\begin{tabular}{|c|c|c|c|}
\hline 69,264 & $-23,146$ & 161,617 & 4 \\
\hline 86,855 & $-137,695$ & 59,327 & 4 \\
\hline$-15,438$ & $-29,616$ & 865 & 3 \\
\hline$-18,987$ & 191,925 & 238,113 & 4 \\
\hline 60,951 & 76,206 & $-199,349$ & 3 \\
\hline 23,981 & $-30,024$ & 1,901 & 5 \\
\hline 49,912 & 28,385 & $-114,008$ & 4 \\
\hline$-134,495$ & 164,855 & $-27,859$ & 3 \\
\hline$-11,111$ & $-48,615$ & $-182,331$ & 4 \\
\hline 174,374 & 73,873 & 37,173 & 4 \\
\hline$-108,015$ & 55,599 & $-2,321$ & 2 \\
\hline 14,515 & 52,986 & 65,561 & 5 \\
\hline 545 & 105,616 & 104,906 & 5 \\
\hline 109,768 & $-30,486$ & 38,275 & 5 \\
\hline$-146,849$ & 7,697 & 116,327 & 4 \\
\hline 11,641 & 38,594 & 63,898 & 4 \\
\hline 12,722 & 68,073 & $-41,917$ & 3 \\
\hline 34,555 & 145,803 & 42,846 & 4 \\
\hline 67,689 & 103,601 & $-64,841$ & 5 \\
\hline$-1,559$ & 29,519 & 17,232 & 4 \\
\hline 59,344 & $-66,843$ & $-41,129$ & 4 \\
\hline 119,815 & $-18,178$ & $-38,559$ & 3 \\
\hline 32,028 & $-61,518$ & $-87,534$ & 4 \\
\hline$-98,707$ & 137,011 & $-226,361$ & 3 \\
\hline$-164,652$ & $-8,605$ & $-27,073$ & 3 \\
\hline$-132,366$ & $-41,138$ & 119,248 & 4 \\
\hline
\end{tabular}


Vol.01, No. 2, 2018

\begin{tabular}{|c|c|c|c|}
\hline$-110,255$ & 63,446 & 72,283 & 4 \\
\hline$-112,966$ & $-251,579$ & 8,905 & 3 \\
\hline$-147,909$ & $-113,486$ & 124,646 & 4 \\
\hline$-37,421$ & 6,582 & 59,602 & 4 \\
\hline$-55,653$ & 138,507 & $-131,303$ & 4 \\
\hline$-96,201$ & $-162,708$ & 195,464 & 4 \\
\hline 159,634 & 415 & 68,483 & 5 \\
\hline 158,551 & 81,452 & $-11,219$ & 5 \\
\hline$-204,195$ & 7,951 & 50,116 & 4 \\
\hline 7,431 & 85,417 & 25,555 & 4 \\
\hline$-89,868$ & $-36,666$ & $-79,149$ & 4 \\
\hline$-22,938$ & $-42,254$ & 62,523 & 4 \\
\hline 62,411 & 14,911 & 79,033 & 3 \\
\hline 158,551 & 81,452 & $-11,219$ & 4 \\
\hline 36,571 & 120,704 & $-2,573$ & 3 \\
\hline$-4,199$ & 162,154 & 36,792 & 4 \\
\hline$-58,759$ & $-91,471$ & 19,445 & 3 \\
\hline 124,145 & $-28,011$ & 1,182 & 4 \\
\hline 34,984 & $-163,998$ & $-94,923$ & 3 \\
\hline$-2,296$ & $-5,343$ & 32,887 & 4 \\
\hline 76,796 & 31,716 & $-121,321$ & 4 \\
\hline$-8,967$ & 19,796 & 57,386 & 3 \\
\hline$-48,313$ & 39,474 & $-49,947$ & 3 \\
\hline 58,778 & 160,374 & 164,274 & 5 \\
\hline 23,598 & $-217,563$ & $-63,561$ & 3 \\
\hline$-93,308$ & $-38,425$ & $-7,894$ & 4 \\
\hline
\end{tabular}


Vol.01, No. 2, 2018

\begin{tabular}{|r|r|r|r|}
\hline 167,004 & 39,012 & 52,828 & 5 \\
\hline 53,882 & $-75,493$ & $-100,268$ & 4 \\
\hline 7,372 & $-64,368$ & $-67,583$ & 4 \\
\hline 96,936 & $-73,997$ & -521 & 4 \\
\hline 73,828 & $-115,679$ & $-38,208$ & 4 \\
\hline$-65,712$ & $-123,676$ & 21,255 & 4 \\
\hline$-132,496$ & 208,657 & 1,852 & 4 \\
\hline 4,741 & $-9,171$ & 17,435 & 5 \\
\hline 108,709 & $-151,669$ & 46,593 & 5 \\
\hline 3,211 & $-117,451$ & 87,872 & 5 \\
\hline
\end{tabular}

